\title{
Critical success factors when going global: the basic challenge
}

\author{
J.S. ROWARTH, A.P. SCOTT, T.O.R. MACDONALD, S.C. WILSON and F.G. SCRIMGEOUR \\ Waikato Management School, The University of Waikato, Private Bag 3240, Hamilton, New Zealand
}

JRowarth@waikato.ac.nz

\begin{abstract}
The Government's Growth Agenda is to increase the ratio of exports to GDP from the current $30 \%$ to $40 \%$ by 2025 . New Zealand agribusinesses of all types are being urged to use knowledge and expertise overseas to increase export revenue in order to assist with achieving the agenda. Over the last two decades there have been numerous attempts to "go global" with varied success. There have also been a considerable number of commissioned reports on how companies should proceed. Pastoral farmers rely on their processors and marketers to return an income to their business, but some co-operatives and companies are more successful than others. This paper gives the background for the case studies in the three papers which follow comparing (a) export strategies for dairy companies, (b) increasing suppliers/customers for co-operative companies and (c) taking New Zealand knowledge and expertise in farming systems offshore.
\end{abstract}

Keywords: Export, relationships, supply-chain, value-add

\section{Introduction}

The goal of the Government's Growth Agenda is to improve the income and wealth for New Zealanders. This is to be achieved by increasing the ratio of exports to GDP from the current $30 \%$ to $40 \%$ by 2025 . Ministers Bill English and Steven Joyce have stated that achieving this goal "will require a concerted effort to encourage investors to develop more internationally competitive businesses, in both the commodity and high-value technology-based sectors" (New Zealand Government 2012a).

The Agenda builds on a considerable number of reports over the last few years attempting to define what it takes to be successful overseas, noting that export success can create a "virtuous cycle" (Stephenson \& Ballingall 2012). Grassland farmers, researchers, industry professionals and policy analysts are all part of the innovation value chain and can influence direction of the companies with which they choose to engage. As a consequence, all have a part to play in assisting global expansion. This paper reviews the reports and distils the key points for examination. It sets the scene for case study research examining the different strategies that agribusinesses have used to expand operations into other countries (McDonald \& Rowarth 2013; Scott et al. 2013; Wilson \& Rowarth 2013), with a view to determining critical success factors, as well as pitfalls to be avoided.

\section{Economic Growth}

Economic growth can be achieved by increasing the quantity of inputs (i.e., capital and labour) that go into production, or by discovering and applying new ways to produce more with the same quantity of inputs (i.e., innovation) (New Zealand Government 2012b). For the primary sector, economic growth is linked to export markets. Primary products account for $70 \%$ of the value of goods exported, and approximately half of the goods exported are unprocessed. A significant proportion of export growth in the last decade has been from the primary sector, and primary production is considered to be key to enhanced growth (New Zealand Government 2012b). Grassland farmers are the foundation for achieving growth and improved returns through the innovation value chain.

A multitude of Government and industry initiatives have been undertaken in order to assist New Zealand companies to expand into overseas markets. In the process, a plethora of documents have been produced from a range of august bodies indicating the magnitude of the challenge. Watts (2008) concluded that decisions on expanding overseas were highly dependent on individual business circumstances, whereas The New Zealand Institute of Economic Research has suggested that the fundamental challenge for New Zealand is that the population is insufficiently large to allow the development of strong domestic companies. Population growth to 15 million was recommended (Stephenson \& Ballingall 2012).

\section{Performance of Small and Medium Enterprises}

Most New Zealand companies are classified as Small and Medium Enterprises (SMEs); a fundamental problem with SMEs is simply scale. As a consequence they are constrained by their level of human and intellectual capital, limited equity capital and limited international business relationships. These constraints need not be fatal if we recognise, as per Watts (2008), that the challenge is one of both opportunity and strategy, and that there is an existing literature that has identified factors that facilitate success. 
Jaeger \& Rudzki (2007) identify the entrepreneurial spirit (passion) as vital for successful business expansion. Passion is essential for overcoming the numerous challenges to expansion (including geographical isolation, a small domestic market platform and the difficulty of estimating the nature and size of overseas markets (Gendall et al. 2010)) while sustaining the commitment to the dream. This in part explains why once a certain size of business has been reached, enthusiasm for further growth often wanes (the Bach, Boat and BMW mentality; New Zealand Trade and Enterprise 2009).

Passion must be associated with products that consumers want and value. Identification of the market and market demand for the product is critical. As Saunders et al. (2011) noted, better positioning of existing products in export markets, value added processing, and niche production and marketing are routes to gain increased returns to farmers. Further, this requires effective branding, personalised customer service, and a strong passion for the product and products (Saunders et al. 2011).

$\mathrm{Ng}$ \& Kee (2012) stress that development of relationships in other countries is paramount; they suggest that it is the intangible factors such as leadership, innovation, entrepreneurial competencies, image and reputation, and organisational culture that make the difference between success and failure in global expansion.

The literature identifies the many critical factors including entrepreneurial passion, market research, product and product placements, branding, relationships and so forth, but is less clear on "how". Implementation is paramount; hence it is critical that progress is monitored and interpreted. Measuring enterprise performance can assist SMEs succeed through improved planning and better identification of competitive advantages (Corner 2001), and better execution of marketing, financial and human resource strategies. Examination of successful companies supports the need to track non-financial measures such as satisfaction of players along the supply chain, and the development of staff.

\section{Future potential}

Future opportunities offer significant opportunities for international business expansion as demonstrated by the Price Waterhouse Cooper (2012) report commissioned by New Zealand Trade and Enterprise. It analysed the opportunities to New Zealand from, amongst other activities, dairy developments in South America. Establishment of a Global Dairy Fund to leverage New Zealand's intellectual property to develop large scale pastoral dairy farms in South America was recommended, based on the fact that New
Zealand farmers are highly skilled in the sustainable management of pasture and the efficient conversion of that pasture into high quality milk (Price Waterhouse Cooper 2012). The theory is that "the opportunity to apply New Zealand's expertise in South America where there are vast tracts of suitable lands and enormous opportunities to enhance productivity is compelling". The recommendation is founded upon New Zealand's competitive advantage - sustainable management of inputs including animal and plant genetics, and farming and milking systems. On-farm New Zealand has high standards, scale, intensity and a reputation for food safety. Productivity and processing are also high quality, with global trade experience and supply management. For the consumer, brands are trusted because of food safety and consistency of product.

However, the experience of Farming Systems Uruguay, now wholly-owned by Olam, the fact that Synlait is now $39.1 \%$ owned by the Chinese company Bright Dairy, $8.4 \%$ by Japanese company Mitsui and $7.9 \%$ by Netherlands company Friesland Campina, and the news that Ravensdown is planning to exit its Australian joint venture Direct Farm Inputs (which sells fertiliser in South Australia and Victoria), as well as its fertiliser operations in Western Australia (where a pretax loss of \$23 million was recorded (Morrison 2013)) indicates that expansion of New Zealand companies overseas is fraught with pitfalls. The Sanlu incident with melamine in China is also an indicator of major potential issues working in countries with a different culture, as is the Zespri double accounting issue which has come to light this year. Hence in addition to an opportunity and a strategy there has to be the capability to deliver the strategy.

\section{Scale and the Supply Chain}

A World Bank policy research working paper released last year (Freund \& Pierola 2012) reported that small firms rarely make "export superstars". In the analysis of the trade data of 32 countries, the largest $5 \%$ of firms were found to contribute $80 \%$ of exports and the top $10 \%$ supplied $90 \%$. The authors identified that export superstars were born big or achieved size very quickly and were responsible for most of the export growth, diversification, employment, and drive comparative advantage. They concluded that disproportionately allocating resources to encourage SMEs to grow might be misguided. Instead, fostering the development of large firms creates jobs, improves productivity, encourages export growth and enables diversification.

With only one large export company in New Zealand, Fonterra, which was "born large" in 2002, strategies to assist SME's work together must be found. Aggregation of small businesses into groups to gain the advantages 
of large businesses could be effective. Aggregation could be horizontal (discussed over the years by meat company suppliers) or vertically at different stages of the supply chain. Of particular importance in gaining greater returns for shareholders is achieving what is termed the Holy Grail of operations managers - a true Demand-Driven Supply Chain (DDSC). Research (Budd et al. 2012) indicates that companies with advanced DDSC improve performance by $20 \%$ and reduce supply chain costs dramatically. Achieving DDSC in primary production with fluctuating supply (Sporleder \& Borland 2011) will require co-ordination as well as advanced technologies and processes that can "react to real-time demand signals across a network of customers, suppliers and employees". DDSC relies on visibility (transparent demand and inventory levels across the supply chain), infrastructure (allowing supply chain players to adapt quickly to short-term changes in supply and demand), co-ordination (to allow flawless execution and cost effectiveness) and optimisation (aiming at delivering the best customer service as well as reducing costs thereby reaping financial benefits).

The goal of a DDSC is to align and co-ordinate. Whereas the traditional model for vertical integration involves one company buying others along the supply chain, DDSC can involve individual companies operating at different points utilising their specific expertise and sharing information to enable the same benefits as achieved by a large company. DDSC are becoming increasingly important as supply chains become more global and complex and as new challenges arise.

In New Zealand, Fonterra has the scale to achieve efficiencies through complex and technologically advanced tracking. However, rapid expansion offshore has involved farmer money and some shareholders have opted to sell up and supply other milk companies: when Fonterra was formed it was supplied by $96 \%$ of New Zealand dairy farmers; in 2011/12 (latest data) Fonterra's stated 10500 farmers were $89 \%$ of the total number (New Zealand Dairy Statistics 2011-2012). In addition, $20 \%$ of shareholders opted to sell economic rights to their shares this year.

The meat companies are much smaller in scale, and their supply chain is neither secured nor tight. The suggestion of greater co-operation between them could achieve the synergies and hence efficiencies gained by larger companies such as suppliers, but the culture in New Zealand is not conducive to cooperation (New Zealand Trade and Enterprise 2009). This has been seen repeatedly with discussions on meat company restructuring.

\section{Relationships}

A common theme in the "how to go global" reports is the importance of relationships. They are critical within the company and between companies. Good relationships, whether with the end-user or intermediaries in the distribution channel, are vital as they control the purchasing. New Zealand Trade and Enterprise (2009) suggested that any customer relationship should involve receptiveness to feed back and the adoption of a lifetime value model where margin, frequency of purchase and duration of purchasing relationship are all considered.

Staff relationships are equally important, both within hierarchies, within a team or business unit and between teams and business units. A culture which rewards talent and encourages innovation creates value for the company (Strack et al. 2012), but New Zealand companies rate poorly in studies on quality of people management (10th out of 17 countries; Ministry of Economic Development 2011). In rewarding top performance New Zealand scored 8th out of 16 countries, in retaining high performers 14 th, promoting high performers 13th and addressing poor performance 16th out of 16. Creating the right culture and developing the workforce is of paramount importance for national productivity as well as global expansion.

\section{Conclusions}

New Zealand has always been an exporting nation, and has always adapted to the strictures of consumer demand and environment. The commodity mentality that still exists through the price-taking global dairy trade auction has been challenged over many years, but breaking out of it has not proved easy - hence the number of reports available. By examining the strategies, leadership, supply chains, marketing and relationships that have allowed companies to take advantage of opportunities overseas, a framework of critical success factors has been identified for a range of companies with a range of goals.

The case studies described in the subsequent papers involved trios of companies with a common theme: dairy added value (Scott et al. 2013), co-operative structure (McDonald \& Rowarth 2013) and New Zealand farming knowledge (Wilson \& Rowarth 2013). The studies compared the strategies and experiences of the chosen companies in an attempt to identify success factors and pitfalls using a basic case study framework (Lewis et al. 1991).

\section{REFERENCES}

Budd, J.; Knizek, C.; Tevelson, R. 2012. The demanddriven supply chain: making it work and delivering results. Boston Consulting Group 2012. 14p. 
Corner, P. 2001. Improving the performance of New Zealand SMEs: measures for success. Business Review 3: 51-66.

Freund, C.; Pierola, M.D. 2012. Export Superstars. Policy Research Working Paper 6222. The World Bank. 40pp.

Gendall, P.; Charbonneau, J.; Henricksen, B. 2010. New Zealand niche marketers : critical success factors. Australia New Zealand Marketing Academy Conference. anzmac2010.org/proceedings/pdf/ anzmac10Final00181.pdf. Accessed May 2013

Jaeger, S.; Rudzki, R. 2007. How SMEs engage in the global economy - cases from New Zealand. Proceedings of the Oxford Business and Economics Conference, 24-26 June, Oxford, p3-12.

Lewis, G.; Morkel, A.; Hubbard, G. 1991. Cases in Australian strategic management. Prentice Hall, New York. 387 pp.

Macdonald, T.O.R.; Rowarth, J.S. 2013. Critical success factors when going global: agribusiness co-operatives. Proceedings of the New Zealand Grassland Association 75: 55-60.

Ministry of Economic Development. 2011. Management matters in New Zealand. www.med. govt.nz. Accessed May 2013.

Morrison, T. 2013. Farmer rebate goes as Ravensdown earnings slump. National Business Review. http:// www.nbr.co.nz/article/farmer-rebate-goesravensdown-earnings-slump-bd-144396. Accessed August 2013.

New Zealand Dairy Statistics 2011-2012. 2013. http:// www.dairynz.co.nz/file/fileid/45159. Accessed August 2013.

New Zealand Government. 2012a. The Business Growth Agenda Progress Reports: Building Export Markets. www.mbie.govt.nz Accessed May 2013.

New Zealand Government. 2012b. The Business Growth Agenda Progress Reports: Innovation. www. mbie.govt.nz. Accessed May 2013.
New Zealand Trade and Enterprise. 2009. Playing to our strengths: creating value for Kiwi firms. www. med.govt.nz. Accessed May 2013.

Ng, H.S.; Kee, D.M.H. 2012. Development of intangible factors for SME success in a developing country. International Journal of Academic Research in Business and Social Sciences 2: 198-213.

Price Waterhouse Cooper. 2012. New Zealand Agribusiness South America and China: opportunities and recommendations. www.nzte.govt.nz. Accessed May 2013.

Saunders, C.; McDonald, H.; Driver, T. 2011. Enhancing value for New Zealand farmers by improving the value chain. Agribusiness and Economics Research Unit Research Report No. 324. 12p.

Scott, A.P.; Bowden, S.; Rowarth, J.S. 2013. Critical success factors when going global: dairy company strategies. Proceedings of the New Zealand Grassland Association 75: 61-66.

Sporleder, T.L.; Boland, M.A. 2011. Exclusivity of agrifood supply chains: seven fundamental economic characteristics. International Food and Agribusiness Management Review 14: 27-52.

Stephenson, J.; Ballingall, J. 2012. Lifting Export Potential: actions to drive growth in exports. New Zealand Institute of Economic Research 30pp.

Strack, R.; Caye, J-M.; von der Linden, C.; Quiroe, H.; Haen, P. 2012. From capability to profitability: realizing the value of people management. The Boston Consulting Group. 13pp.

Watts, T. 2008. Strategies for New Zealand manufacturing small and medium sized enterprises going global. Unpubl. Masters Thesis, Massey University.

Wilson, S.C.; Rowarth, J.S. 2013. Critical success factors when going global: New Zealand farming systems overseas. Proceedings of the New Zealand Grassland Association 75: 49-54. 